\title{
Absolutism in Religion and Global Peace: Boko-Haram Factor in Nigeria and Its Educational Imperatives
}

\author{
Muhammad Mann Shaaba ${ }^{1, *}$ \\ ${ }^{1}$ Department Of Educational, Foundation and Management, Federal College of Education, Kontagora, Niger State, \\ Nigeria \\ *Correspondence: Department Of Educational, Foundation and Management, Federal College of Education, \\ Kontagora, Niger State, Nigeria. Tel: 234-803-831-3559. E-mail: Shaabamann@Yahoo.Com
}

Received: January 11, $2017 \quad$ Accepted: February 11, $2017 \quad$ Online Published: April 10, 2017

doi:10.5430/wje.v7n2p11 URL: https://doi.org/10.5430/wje.v7n2p11

\begin{abstract}
Nigeria, hitherto regarded as a relatively peaceful country at least in terms of terrorism, became a globally notable country with high incidence of religious violence and outright terrorism. This paper discussed Boko-haram as the Nigerian terrorist group that started from a small local group in Borno State of the country and grew into an international terrorist body that was found to be among the deadliest in the world. The group's exclusively claim to absolute truth about Islam made it to strongly believe in its ideas. It also motivated the members to sacrifice their lives for violent propagation of Islam and hatred for western education. In order to prevent future terrorism, education was not only seen as imperative, but as the most enduring solution. Such education, according to the paper should involve classroom teaching that is organized on the basis of Harmony Education which emphasize the principles of understanding and appreciating whatever is presented to a learner before accepting or rejecting it rationally in a way that tolerates people with different views.
\end{abstract}

Keywords: Absolutism; Boko-Haram; global peace; classroom teaching

\section{Introduction}

Continuous religious conflicts in Nigeria have given many Nigerians and indeed the entire world great cause for concern in recent years. Many people wonder why "religion which used to be the cohesive factor and core of national unity, peaceful co-existence and national development has become a tool for violence, destruction of lives and property in Nigeria" (Ushe, 2015. P. 117). How did religious practice terminate the sense of tolerance, open mindedness, love and empathy of some Nigerians that became terrorists? Is there anything inherent in religion that made some Nigerians to say goodbye to the days when Nigerians were regarded as people who are not heartless enough to do suicide bombing? Could absolutism in religion be part of the causative factors that changed some Nigerians to develop a Nigerian made terrorist group called Boko Haram? This paper is interested in answering the questions above and related ones including how absolutism in religion has jeopardized global peace.

From the educational perspectives, the paper will also discuss the anti western education philosophy of Boko-Haram with the aim of further understanding the thinking of the terrorists and the philosophy guiding their activities. An understanding of the terrorist's philosophy is predicated on the assertion that "until we understand a man's ignorance, we are ignorant of his understanding" (Coleridge in Oyeshile, 2008 p. 215). Such understanding can further enable Nigerians and indeed, the entire world to plan, how to educate young and adult learners in the classroom with the view of enhancing peaceful coexistence and preventing future recruitment of school leavers into terrorists folds

\section{Methodology}

The method of intellectual discourse in philosophy of education was used in this paper. According to Bamisaiye (2012), intellectual discourse means the selection of an idea/issues for a critical examination with the aim of taking a position on logical grounds. It is important to state that intellectual discourse is a method in philosophical of 
education has its own peculiarities which include the fact that it is book-based (Bamisaye, 2012); it does not see any interested subjects, so there is no empirical findings (results) (Enoh, 2017). Also, it does not limit literature review to a single chapter. Rather, literature review is spread throughout the research ultimately ensure critical interpretation, deep understanding, rigorous criticism and open minded evaluation of ideas, issues and concepts so as to put them in context. (Enoh, 2012, Onwuka, 2012 Babarinde, 2012 Adesanya 2012 and Akinpelu, 2012). Accordingly, Absolutism in religion and Boko Haram as a terrorist group in Nigeria were critically examined in relation to global peace and how education can be used to prevent terrorism.

\section{Emergence of Boko-Haram as a Terrorist Group}

Given the fact that Boko-Haram as a terrorist group is very central to the paper, there is a strong need to give a historical overview of how the body emerged before going to any theoretical exposition. The real origin of the body can be traced back to 1995 when a Muslim Youth organization called Shabaab under the leadership of Abubakar Lawan was formed in Maiduguri. (Muhammad 2015). The ultimate aim of the body was to encourage Muslims starting with the youths to live what they believe is the puritan Islamic life. The command later shifted to Yusuf Mohammed when Lawan departed for studies in Saudi Arabia. After the take over, Yusuf and his students in 2002 established their own movement known as "Jama'at Ahl Us-Sunnah Li'd Da'Wah Mal'Jihad" (the group of people of Sunnah for preaching and jihad) (Oduyela, 2014).

Yusuf indoctrinated the sect with his own teaching which he claimed were based on purity. Yusuf perception of "purity" and teaching were inspired by the works of Ibn Taymiyya, a $14^{\text {th }}$ century Islamic scholar who preached Islamic fundamentalism and is regarded as a chief philosopher of radicalism in the Middle East. (Johnson, 2012). At the beginning, the sect recruited its members from school drop-outs and unemployed university and polytechnic graduates, most of whom tore up their certificates because they saw them as worthless worldly papers. Students, male and female withdrew from school to join the group. Yusuf "made his members to believe that their state of despair was caused by government which imposed western education on them and failed to manage the resources of the country to their benefits". (Oduyela, 2014 p.3). This assertion, according to the jihad group makes western education "prohibitive and sinful (Haram) in Arabic.

The radical preaching of Yusuf continued to cause increasing concern in government circles until 2009 when major violence erupted between the jihadists and the government that resulted into the death of Muhammed Yusuf. A new leader for the group emerged in the person of Abubakar Shekau who turned out to be ruthless and vicious with human life. Shekau described himself as a person who enjoys killing any one that God command him to kill because human life to him is like lives of chicken and rams (BBC in Alozienwa, 2012). Thousands of lives from Nigeria and beyond were lost and property worth millions of naira destroyed including the United Nations House in Abuja which Shekau described as a forum of all the global evils (Thisday, September 19, 2015). A major terrorist activity of book-haram was the kidnap of over 200 secondary school girls from Chibok, Borno State in April, 2014. Boko-Haram started from a small local group in Borno State of Nigeria and metamorphosed into an international terrorist organization that has jeopardized global peace.

\section{Theoretical Considerations}

In order to understand Boko-Haram terrorist group properly, there is need to do a theoretical explanation of the idea of absolutism which is a major working concept of terrorism.

\subsection{Absolutism, a Seed for Terrorism}

The term absolutism has both a moral and political connotation (New World Encyclopedia, 2016). In morality, absolutism refers, at least to two distinct doctrines. In the first place, it may refer to the claim that there exists a universally valid moral system, which applies to everyone whether they realize it or not. In the second place, absolutism may also refer to the claim that moral rules or principles do not admit any exceptions. In politics, absolutism refers to a type of government in which the leaders power is not subject to any legal constraint.

In contrast, the relativists contend that it is possible to have moral principles accepted by everybody but certainly not applicable to those who do not accept them. For example, globalization has made western culture widespread across continents, but not widely applicable to people who did not endorse it. In other words "the relativist would argue that a moral code could be universally accepted, without being universally valid, and hence fail to be absolute". (New Encyclopedia in www.newworldencyclopedia).

Thomas Hobbes (1588-1679) provided a penetrating and influential philosophical justification for absolutism 
(http:history-world.org/absolutism). The French religious wars and English civil war of the 1640s inclined Hobbes to view order as the primary social good, while anarchy is the greatest social disaster. According to Hobbes, people created governments as protection against themselves because they were naturally "brutish" "nasty" "selfish" and cruel. Having been forced by human nature to surrender their freedoms to the state, people no longer have any right remaining under the government expect obedience and absolute obedience for that matter.

From a Godly perspective, Bishop Jacque Bossuet (1627-1704) a prominent French church man provided another philosophical justification for absolutism (http:history.world.org/absolutism). According to him, the person of the king is sacred and to attack him in any way, is therefore sacrilege; the royal throne is the throne of God not of a man; the royal power is so absolute that the king does not need to render accounts of his action to any one. Bishop Bossuet further maintained that the world of a king is synonymous to power and that the king needs absolute authority to do good or repress evil. In other words, absolutism, going by the above expositions, implies that there could be an unquestionable human power, an unquestionable idea and an unquestionable thinking and an unquestionable group like Boko-Haram. Absolutism has penetrated religion so much that, terror experts qualify "absolutism as "the seed of extremist ideology" (Saad, 2015 p. 1); a situation that is of serious concern in the Muslim world.

In Malaysia, for example, second Home Affairs Minister, Masagas Zulkifli expressed concern over what he calls the phenomenon of absolutism that has crept into the Malay Muslim Community (Saad, 2015). In furtherance of the concern, Dr. Mohamed Ali, Vice-Chair of the Religious Rehabilitation Group reinterated that "if we study the characteristics of extremist ideology, we find that absolutism is one of their key characteristics" (Saad, 2015 p. 2). According to Dr. Mohammed Ali, it is important that Muslims should not be absolutist as Islam encourages its adherents to tolerate the teaching of others, whether it is inter-faith or intra-faith; Muslim must be open to other thoughts and ideas and should embrace diversity and pluralism.

In Nigeria, President Muhammed Buhari publicly ascribed the tag evil to Boko-Haram thus:

The perpetuators may look like human beings, they may have limbs and faces like the rest of us but they are not like us. In killing innocent people they have become in human...These terrorist subsist outside the scope of rational humanity. Their mother is carnage and their father is cruelity.

(Ocholi, 2015 p. 12)

In a related manner, the Sultan of Sokoto Alhaji Saad Abubakar, the official leader of Muslims in Nigeria rejected Boko-Haram, thus; "Islam is a religion of peace... terrorism has no place in Islam" (Vanguard 2014, p. 1). It can therefore be seen that absolutism is indeed the seed of terrorism and conversely terrorism is an out growth of absolutism

\subsection{Claims to Absolute Truth-A Catalyst to Violence}

The word "truth" is so commonly used by everybody in all spheres of life that it (the word) is often taken for granted; not many people think of the need to be caustions in qualifying their position on things or issues as "the truth". While "a truth" presupposes that there are other truths about the issue or idea in question, "the truth' implies an element of absoluteness; lack of recognition for any other possible truth. On the other hand, also, statement like "all truth is relative" or "absolute truth" does not exist" are themselves laying claim to absolute truth. In other words, claim to absolute truth is as absolute as absolute claim to relative truth'. What then is safe to do; not what then is the safest thing to do because the latter connotes absolutism in a way. Dr. Charles Kimbal's view of truth is a possible way out, especially on religious matters which are usually emotional and may be uncompromising.

According to him in Langness (2014)
A human view of truth, one that is dynamic and relational, enables religious people to embrace and affirm foundational truths without necessarily solidifying the words into static, absolute, propositional statements. Conversely religious convictions that become locked into absolute truth can easily lead people to see themselves as God's agents. People so emboldened are capable of violent and destructive behavior in the name of religion (p.1).

A dynamic concept of truth gives room to the philosophical qualities of open mindedness, critical thinking, tolerance, freedom and mutual respect, all of which enhances proper human relation and societal peace. Dynamism in conceptualizing truth is further justified by the fact that "human understanding, human appreciation and perception 
of truth is relative based upon the knowledge, the training, the exposure, the intelligence and the number of variables relating to the individual making the decision" (Amjad, 2016 p. 1).

On the other hand, an absolute concept of truth, especially absolutism that is exclusively claimed by an individual or group of individuals breed arrogance, intolerance and all forms of destructive tendencies especially, on religious matters. This is why Abubakar Shekkau, arguably the most vicious of Boko-Haram leaders described himself as somebody who enjoy killing anyone that God commands me to kill the way I enjoy killing chickens and rams (BBC in Alozienwa, 2012). True to this description, an eye witness who escaped death when 100 men were killed in the town of Madagah, Borno State in one day said:

\section{Before they got to my group, they killed (slaughtered) 27 people in front of me. I was counting everyone of them because I wanted to know when my turn would come... when they got to my turn the executioners knife got too dull to slit any more throats" (Kawzloska 2015. P.4)}

It can therefore be seen that, although, no single theory can exclusively explain the motivation of terrorist (Simon, 2011 p. 1), absolutism in religious faith is no doubt a fundamental factor, a driving force in the operation of Boko-Haram insurgency in Nigeria. Is there any relationship between absolutism and the philosophy of education of Boko-Haram. A further explanation could reveal this.

\subsection{Boko Haram's Anti Western Education Philosophy in the Midst Of Poverty}

Every human association formed for one reason or the other operates on the basis of a philosophy that is either formally stated or informally articulated. Boko Haram as a human organization is not an exception to this generation. This body of terrorist has a philosophy that is anchored on hatred for western education. The sect mobilized its members from school drop-outs and unemployed university and polytechnic graduates who saw Boko-Haram as a platform of vetting their anger and frustrations. The recruits, according to Okereke (2011 p. 12) were indoctrinated by the sect to see Western Education as forbidden, while western style of governance/democracy was seen as evil.

Unfortunately, the socio-economic situation of the country provided practical evidence to show that the country is being mismanaged. Katsina (2012), Nwanegbo and Odigo (2015) Roger (2012), Campbell (2014), Ayuba (2015) and Achebe (2015) upheld socio economic factors such as unemployment and poverty as important causative factors of Boko-Haram. Nigeria has a relatively high economic growth, but the fruit of the growth is not reaching majority of the population. Instead the wealth is concentrated in the hands of few, resulting in disempowerment, resentment and anger of the youths. The situation, according to Roger (2012 pp. 2-3):

\section{Has been powerfully captured in 2012 poverty survey by the National Statistical Bureau (NBS) which shows that $60 \%$ of Nigerians are defined as poor, 112 million people - a huge increase from just 17 million in 1980. These figures are serious enough, but the future population trends are alarming. The current population of 163 million is expected to rise on current trends to 389 million by and even 700 million by 2100, according to the United Nation estimates.}

Poverty in Nigeria provided a basis for the leadership of Boko-Haram of Muhammed Yusuf to posit that "western style education is mixed with issues that run contrary to our beliefs in Islam" (Rogers 2012 p.1). Consequently, the terrorist group took it as a duty to fight violently against the western system of education so as to ultimately replace the entire western system of governance with sharia that will provide good education and take care of people's welfare. Their exclusive claim of absolute truth in religion made them to strongly believe in themselves and their interpretation of Islam which provided the motivation they required to sacrifice their lives for violent propagation of Islam and hatred for western education. Eventually, Boko Haram turned out to be a body that notably jeopardized global peace.

\subsection{Religious Terrorism and Nigeria's Ranking in Global Peace Index.}

Using the report of Martin and Simoneli, Muhammad (2014.p.2) aptly stated the deadly nature of Boko Haram, thus:

Although the estimates of total fatalities vary widely between 2009 and 2013, this militant group alone, was responsible for 2.34 percent of the more than 34,000 terrorist attacks that took place worldwide and caused 5.9 percent of fatalities. Headed by Abubakar Shekau since 2010, Boko 
Haram is now considered among the deadliest extremist groups in the world.

In a similar vein, Rowen (2016) characterized Boko Haram as a group that is opposed to western education, western philosophy, and the entire society. It seeks to overthrow the government and implement sharia throughout the country. The groups name translates to "western education is sinful"

The above descriptions are further evidenced by the Global Peace Index (2014.p.1) which ranked Nigeria as the "second most deadly country in the world after Iraq". The rating was caused by frequent attacks by Boko Haram in 2013 and 2014 when Nigeria experienced 140\% increase in Boko Haram caused deaths. In economic terms, the report puts the cost of violence by religious terrorists around the world at a record of $\$ 14.3$ trillion in 2014 . The cost of violence is no doubt hampering Nigeria's economic progress and posing a serious threat to achieving her goal of being among the top 20 economies by 2020 (Harmon 2013). It is therefore, only logical to state that the onus is upon government to ensure that some of the causative factors that are ascribed to violence such as high unemployment, dearth of infrastructure and poverty are forestalled. But is Islam terrorism friendly? This issue will now be addressed.

\subsection{Islam and Diversity Versus Violence and Absolutism}

Islam has a clear vision for building a tolerant non terrorist nation. The Holy Quran invites humanity to inter religious and intercultural understanding and cooperation in trying to achieve harmony and social justice. According to Chapter 49, Verse 13 of the Quran in Musa (2010.p.2):

O people! Indeed, we have created you from a male and a female, and have made you nations and tribes that you may get to know one another. Indeed, the most noble of you, in the sight of God, are those with the most righteous deeds.

The diversity is indicative of God's creative power, wisdom and endowment for human life. According to Sidiqi (2015.p.2) "God wants human beings to derive benefits from this diversity and not to allow it to generate unhealthy schism and division in their ranks". Human diversity is meant to achieve unity in diversity and knowledge of each other; not barriers; not antagonism, not hatred; not terrorism; not violence. Knowledge of each other is ultimately aimed at mutual respect and mutual love.

Islam also recognizes the individuality of each human being as well as the individuality of their groups and communities. God said in Quran 5:48. To each among you, we prescribed a law and an open way. If He (Allah has so willed, he would have made you a single people, but, the plan is to test you in what he has given you; so strive as in a race in all virtues. The goal of you all is the Allah (Siddiqi, 2005). It is He that will show you the truth of the matters in which you dispute. In other words, God Himself alone is the one that will make final judgement on who followed the truth; no human being can pass that final judgement on any body and expect people to follow his human judgement unquestionably. God forbade his prophets and believers from having recourse to coercion in religion. Quran: 2:252 and 2:256 clearly prohibit compulsion in religion (Siddiqi, 2005). Unfortunately terrorists are often extremely passionate about their view points to the extent of uplifting their interpretations of religious injunctions and practices as "absolute interpretations" and "absolute practices" which they consider as compulsory absolute ideals for everybody.

Based on the submission above, it can be stated that diversity according to Islam is anti terrorism and is unavoidable in human affairs. Also, God recognize individuality in human beings and forbids use of violence and coercion to make, people believe. Islam rejects exclusive absolutism in religious beliefs at the expense of tolerance of others, respect for their views and interpretations.

\subsection{Possible Preventive Solution to Boko-Haram: The Imperative of Harmony Education}

The President of Nigeria Muhammadu Buhari in a meeting with the Secretary General of United Nations at Abu Dhabi, the United Arab Emirate told the world that Boko Haram terrorists group have been driven away from the Nation's Territory into "fall-back position" (Wakili, 2016). Despite the setback however it is important to state the reality that Boko Haram is an idea in the terrorists mind; a state of discontent and frustration; a mindset of viciousness and quite importantly a mind of exclusive claim to absolute truth. Such a mind cannot be permanently defeated in the battle field but can best be defeated through education. Roces (2012) quoted prophet Muhammed thus: "The ink of the scholar is more precious than the blood of the martyrs". This clearly shows the importance of education in Islamic religion. Blais (2014) the former Prime Minister of Britain opined that it is imperative to take some educational measures that will re-orientate the identified terrorists and the potential ones because. The soil in which they (terrorists) plant the seeds of hate is fertilized with ignorance. That is why we need to start thinking of 
education as a security issue". The importance of education as an instrument of combarting terrorism is clearly stated by Malala the young education activist in a moving address to the United Nations, thus: "We realized the importance of light when we see darkness. We realize the importance of our voice when we are silenced. We realized the importance of pens and books, when we saw the guns" (Duncan, 2013. p.1). In a memorable conclusion, Malala qualified education as the only solution to terrorism, Prasad (2015) after tracing the history of terrorism and violence from the $15^{\text {th }}$ century reinterated that only education can make human beings just and become non violent.

In view of the above, it is imperative that Nigeria in particular and the entire world in general should go beyond military counter measures in curbing terrorism. They should make the best use of the potential opportunities available in education in preventing violence of all types including terrorism. And this should start right from the classroom teaching of conventional schools and adult education centers. The preventive classroom education may be anchored on what can be called "Harmony Education Triangle" (HET) drawn below:

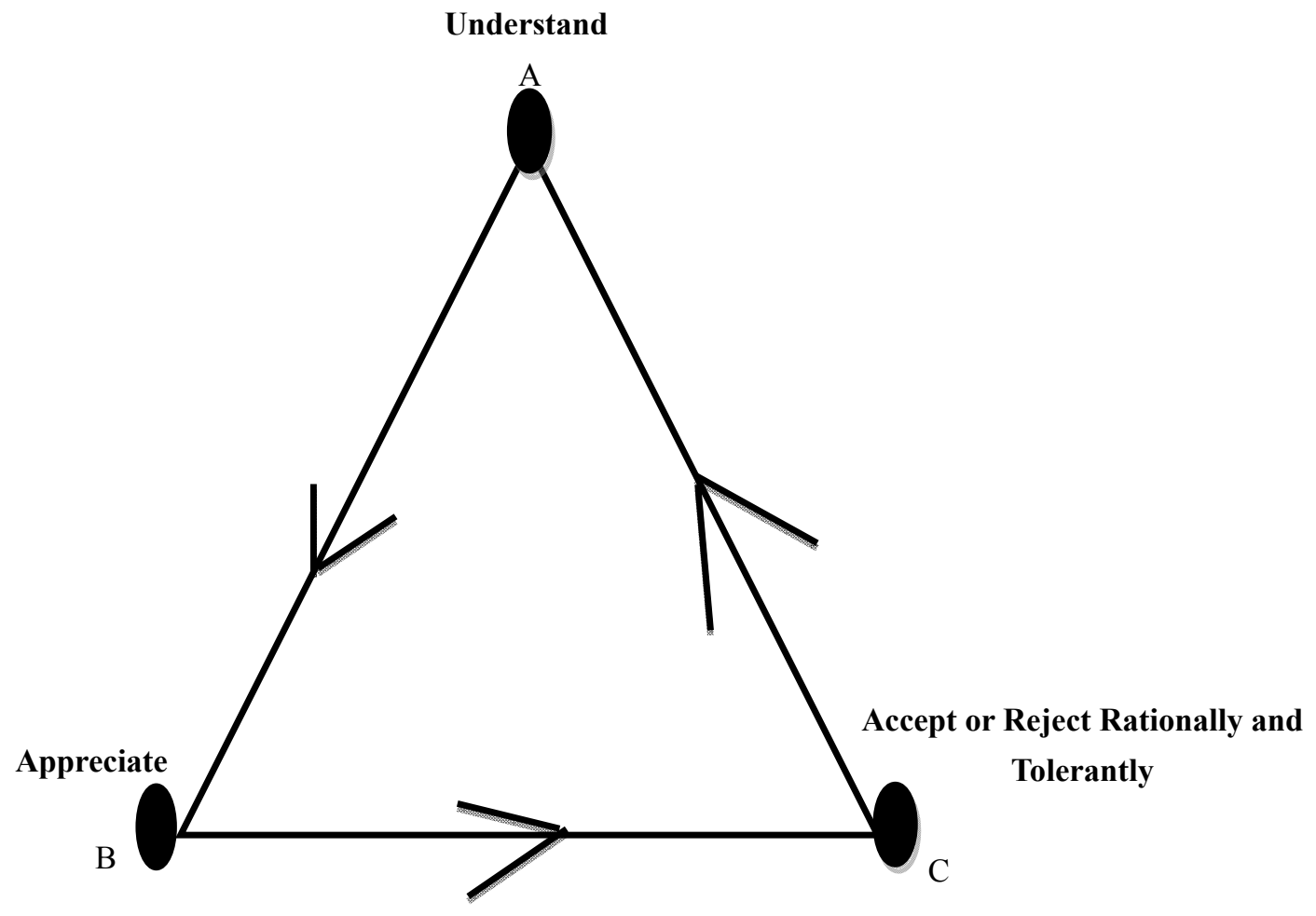

Figure 1: Harmony Education Triangle (HET)

Classroom teachers should encourage discussion of ideas and issues, whether controversial or ordinary. The discussions should be made to undergo the test of passing through the three points of the Harmony Education Triangle A, B, and C In every issue tabled for discussion, the teacher should insist on making the learners to first and foremost understand the issue at stake, make them appreciate the worth or otherwise of the issue before accepting or rejecting the issue. The rejection or acceptance should be done rationally by way of having good reasons for doing so and that should be done with the mindset of tolerance of different views. It is at the acceptance or rejection stage mainly that disharmony happens between people which may result into violence and destruction and possibly terrorism. If all issues or ideas presented to people or discussed by people are accepted or rejected with good reasons and with the mindset that tolerate other peoples, view human disharmony resulting to violence will be minimized drastically. Eventually, terrorism will gradually diminish, global piece will improve and socio-economic development will become sustainable globally.

Institutionalization of Harmony Education Triangle as a strategic methodology of organizing classroom teaching, discussion, debate, dialogue, discourse and deliberation will discourage ignorance, mitigate the negative impacts of absolutism and claim to absolute truth in religion. Each young learner and adult learner will see his or her own point of view as a point of view among many other points of view and not as the absolute view that has exclusive superiority over other views. Rational acceptance or rejection of ideas will increase learners zeal to search for more 
knowledge and understanding, leading to more informed appreciation and more enlightened rejection or acceptance Terrorist groups like Boko-Haram will find it difficult if not impossible to recruit young boys and girls into their folds. Basically, terrorism starts from the mind, and when the mind is occupied by education, that is strategically and methodologically delivered to ultimately inculcate understanding, appreciation and rationality, then the desired psychological obstacle to terrorism becomes effectively functional,

\section{Conclusion}

Terrorism, no doubt is a serious problem all over the world. Contrary to all expectations, a terrorist group by name Boko-Haram emerged in Nigeria and became so vicious that it had notable impact on global peace. Consequently, Nigeria was ranked in 2014 as the second country in the world after Iraq. The paper traced the emergency of Boko-Haram from 1995 as a non-violent movement to the time of Abubakar Shekkau as the leader in 2009 when ruthlessness and viciousness took over. That was the time when thousands of lives were lost and property worth millions of naira were destroyed in Nigeria and the neighbouring countries. The paper did a theoretical exploration of absolutism as a belief that sow the seed of terrorism and catalyzes violence. Absolutism was seen as a major motivational force behind Boko-Haram mayhem.

Furthermore, poverty was identified as a major socio-economic situation that made it possible for Boko-Haram leadership to recruit members and perpetuate the group's anti-western education philosophy. Despite Boko-Haram's claim of Islam as their reason for killing people, the paper showed that Islam: is against violence and terrorism; it is supportive of human diversity and tolerance; and rejects the use of force to make people become Muslims. But, because terrorism is in the mind, it cannot be tackled well enough by military action. Rather, education is seen by the paper as the most enduring solution. In view of this, the paper recommends Harmony Education Triangle (HET) as a possible classroom strategy that can be used to teach in conventional and adult education classes so as to prevent continuous recruitment of new members into terrorism

For further research purpose, scholars in curriculum studies and other branches of education are urged to try the harmony education triangle in practical classroom teaching to find out its possible impact and effect. Further researches can also be done on possible educational strategies that can be used to deradicalize imprisoned terrorists within and outside the prisons.

\section{References}

Adesanya, L.A. (2012). Philosophical Research Methods: Approaches, Challenges and Limitations. In A.O. Enoh and K. Babarinde (Eds.), A Guide to Philosophical Research in Education. Lagos; Stirling-Horden Publishers Ltd.

Akinpelu J.A. (2012). Is there a philosophical research method? In A.O Enoh and K. Babarinde (Eds,), A guide to Philosophical Research in Education. Is there a philosophical research method?

Aliozienwa, S. (2012), contending theories on Nigeria's Security Challenge in the Era of Boko-Haram insurgency. Retrieved from http://www.upeace.org/indx. fm?ejemplan-24 \& entrada-128.

Amjad, M. (2016). Is truth relative or absolute? Retrieved from http://www.understanding.islam.com/q-and-a/sources-of-islam/is truth

Ayoub, M. (2007). Religious pluralism and the Quran. Retrieved from Http://iit.Org/Research/Scholars Summerinstitute/Tableofcontents/Relig.

Babarinde, K. (2012). Tyranny of the Socio-Science Paradigm of knowledge over PRM- Issues and Possibilities for Philosophers of Education. In A.O. Enoh and K. Babarinde (Eds.), A Guide to Philosophical Research in Education. Lagos; Stirling-Horden Publishers Ltd.

Bhashyam, S.S. (2014). The terrorist mindset. Retrieved from http://www.ise.ac.uk/researchAndExperts/research highlights/poli

Blair, T. (2014). How Education can help decrease terrorism. Retrieved from http://themo-slowtimes.com/articles/how-education,can-help-decrease terrorism31069

Campbell, H. (2014). Boko-Haram: economic fundamentalism and improverishment send unemployed Youth into religious militias. Retrieved from www.globa/research/ca

Croucher, S. (2014). When isis jihadists return home: how to deradicalise Islamic extremists. Retrieved from 
http://www.co.uk/when-isis-jihadists. return-home-how-de-1

Duncan, A. (2013). Education is the only solution press@ ed.gov.

Enoh. (2012). Philosophical and Empirical Research in Education as Autonomous and Complementary. In A.O. Enoh and K. Babarinde (Eds.), A Guide to Philosophical Research in Education. Lagos; Stirling-Horden Publishers Ltd

Ezecha, S.I. (2011). Causes and effects of insecurity in nigeria. The national scholar, 8(2).

Global Peace Index (2014). http://www.naij.com/464335. http://www.peace.org/index/cfm? Ejemplan-24 \& extrada 128.

Johnson, T. "Boko-Haram" http://www.cfr.org/africa/boko-haram p25739?cid-ppc.

Kozlowska, H. (2015). The devastating numbers behind Boko-Haram's bloody rule. http://qzcom/383047thedevastating-numbers-behind-Boko-Haram-bl

Langness, D. (2014). No faith is final-religious claim to absolute truth. Retrieved from http://bahaiteaching.org/nofaith-is-final-religious-claims-to-absolute truth.

Muhammad, F. (2014). Understanding the intensity of boko-haram terrorism http://globale.com.org/343.

Musa, A.Y. (2010). What the Quran says about different cultures and religious. Retrieved from http://www.examiner.com/article/what-the-quran says about-different-c.

Newword Encyclopedia (2016). Retrieved from http://newworldencyclopedia.org/entry/absent

Ocholi, D. (2014). Nyanya bomb blast and the fight against terrorism in Nigeria. Verbation Publication of $12^{\text {th }}$ may 2014.

Oduyela, O. (2014). The emergence of boko-haram: from religious intolerance to religious terrorism in Nigeria. Retrieved from http://africaporters.com/2014/05/21/the-emergence

Okereke, N. C. (2011). Implementing the Nigerian Defence Policy. Reflections on the Boko-Haram Crisis" in Mbachi, O. and Sokoto, A.A. (Eds.), Nigerian Defence and Security: Policies and Strategies Kaduna: Medusa Academic Publishers Ltd.

Onwuka, C.J.A. (2012). Challenges of Philosophical Research Method in Contemporary Education. In A.O. Enoh and K. Babarinde (Eds.), A Guide to Philosophical Research in Education. Lagos; Stirling-Horden Publishers Ltd.

Oyeshile, O.A. (1998). A compendium of philosophical and political quotations. Ibadan, Nigeria, hope publications.

Prasad, S.N. (2015). Peace education for non-violence and solution of terrorism. Transcend Media Service. Retrieved from http://www.sitesgoogle.com/site/peace education.

Roces, R.A. (2002). Education solution to poverty and amp; terrorism www.philistar.com? Opinions education.

Rowen, B. (2016). What is Boko-Haram? Islamic sect that opposes western education, terrorizes civilians. Retrieved from http://www.infoplease.com/news/2014/boko-haram

Saad, I. (2015). Channel News Asia. Retrieved from www.channelnew asia.com/.../absolutism.

Shashyam, S.S. (2014). The terrorist mindset. http://www.ise.ac.uk/research and experts/research highlights/poli.

Shehu, S. (2011). "Boko-Haram: history, ideas and revolt" Guardian newspaper of $19^{\text {th }}$ July, 2011

Siddiqi, M. (2005). Unity and diversity: Islamic perspective. Retrieved from http://theamericanmuslim.org/tam.pbp/features/articles/unity-and-diver.

Simon, S. (2011). No single theory can completely explain the motivations of terrorist individual and groups. Retrieved September 19 from http://saidsimon.wordpress.com 2011/05/26/no single-theory-can Thisday2011

Ushe, M.U. (2015). Religious Conflicts and Education in Nigeria: Implications for National Security. Journal of Education and Practice, 6(2).

Vanguard. (2014). Retrieved 27th January, 2016 from www.vanguard.com/2014/06/

Wakili. (2016). Daily Trust of January 19, 2016 